DOI 10.23859/2587-8344-2020-4-4-7

Елена Борисовна Лопатина
Институт славяноведения РАН,
Москва, Россия
https://orcid.org/0000-0002-7718-400X,
ellolebo@gmail.com
Elena B. Lopatina
Institute for Slavic Studies of the RAS,
Moscow, Russia
https://orcid.org/0000-0002-7718-400X,
ellolebo@gmail.com

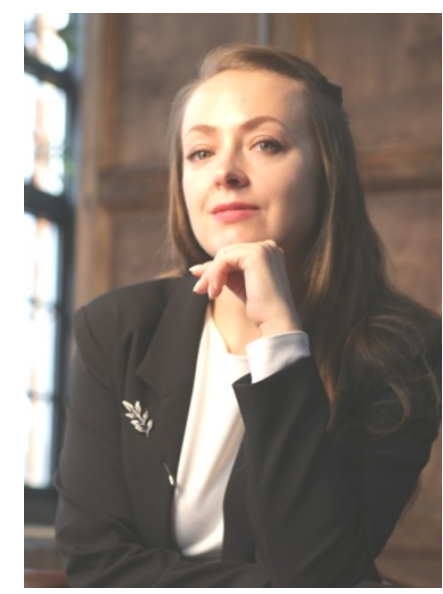

К вопросу о взаимодействии советских властей и польского военно-политического подполья на исходе Второй мировой войны (О статье Д. Рогута «Отношение советских органов безопасности к Армии Крайовой (июль 1944 - январь 1945 гг.)»)*

\title{
On the Issue of Interaction between the Soviet Authorities and the Polish Mili- tary and Political Underground at the End of the Second World War (On the Article by D. Rogut "The Attitude of Soviet Security Organs to the Home Army (July 1944 - January 1945)")
}

Аннотация. В статье представлен анализ взаимодействия советских властей и Армии Крайовой в конце Второй мировой войны, от положительных эпизодов военного сотрудничества до полного разрыва и арестов солдат и офицеров, принадлежавших к отрядам АК. Автор рассматривает причины начала репрессивных действий советской стороны по отношению к польскому политическому подполью и приходит к выводу, что

* Для цитирования: Лопатина Е.Б. К вопросу о взаимодействии советских властей и польского военно-политического подполья на исходе Второй мировой войны (О статье Д. Рогута «Отношение советских органов безопасности к Армии Крайовой (июль 1944 январь 1945 гг.)») // Historia Provinciae - Журнал региональной истории. - 2020. - Т. 4. № 4. - C. 1352-1359. DOI: 10.23859/2587-8344-2020-4-4-7

For citation: Lopatina, E. On the Issue of Interaction between the Soviet Authorities and the Polish Military and Political Underground at the End of the Second World War (On the Article by D. Rogut "The Attitude of Soviet Security Organs to the Home Army" (July 1944 - January 1945)"). Historia Provinciae - The Journal of Regional History, vol. 4, no. 4 (2020): 1352-59, http://doi.org/10.23859/2587-8344-2020-4-4-7

(C) Лопатина Е.Б., 2020

(C) Lopatina E., 2020 
действия и польской, и советской стороны были обусловлены попыткой обеспечить национально-государственные интересы посредством создания у своих границ пояса безопасных территорий.

Ключевые слова: СССР, Армия Крайова, Красная Армия, польское подполье, национально-государственные интересы.

Abstract. The article analyses the interaction between the Soviet authorities and the Home Army at the end of the Second World War, from positive episodes in military cooperation to complete rupture and arrests of soldiers and officers who belonged to the Home Army detachments. The author examines the reasons for the commencement of repressive actions of the Soviet side against the Polish political underground and concludes that the actions of both the Polish and the Soviet sides were caused by an attempt to ensure national and state interests by creating a zone of safe territories near their borders.

Key words: USSR, Home Army, Red Army, Polish Underground, national and state interests

Проблема взаимодействия советских властей и Армии Крайовой является предметом обширной историографии. Особое внимание исследователей обращено к вопросам, связанным с контактами между частями Красной Армии и отрядами Армии Крайовой (далее - АК) после января 1944 года, когда Красная Армия пересекла довоенную границу с Польшей и в её тылу оказались различные по национальному составу и по политическим взглядам партизанские отряды, в том числе подразделения АК - самой крупной подпольной вооруженной организации, подчинявшейся польскому правительству в Лондоне. Безусловно, не обошли стороной этот сюжет и российские исследователи.

О значимом интересе к проблеме со стороны современной российской исторической науки свидетельствует, в том числе, издание трехтомного сборника документов «Советский Союз и польское военно-политическое подполье, апрель 1943 - декабрь 1945» ${ }^{1}$. В контексте отношения советских властей к солдатам и офицерам АК составители сборника сделали акцент на том, что советское командование с начала 1944 г. решало сложную военно-политическую задачу не допустить действия в своем тылу неподчиненных ему вооруженных групп, что приводило к разоружению, а при сопротивлении - подавлению деятельности партизанских отрядов и интернированию офицеров АК. Решение данной задачи и обусловило отношение к АК со стороны советских органов безопасности.

Предлагаемая вниманию читателей статья Д. Рогута написана на основе глубокого знания современной польской и российской историографии и источниковых материалов. Автор прослеживает контакты Красной Армии и отрядов

${ }^{1}$ Советский Союз и польское военно-политическое подполье, апрель 1943 г. - декабрь 1945 г.: в 3 т. / под редакцией А.Н. Артизова. - Москва: МФД: Демократия, 2018-2020. 
АК с весны 1944 года, с момента кратковременного успешного взаимодействия АК с войсками 2-го Белорусского фронта в борьбе против гитлеровцев. Однако, как справедливо отмечает Д. Рогут, в результате совместных действий между АК и Красной Армией весной 1944 года постоянное сотрудничество налажено не было, более того, часть 27-й пехотной дивизии АК была разоружена Советами. Автор статьи не указывает, почему короткое эффективное военное взаимодействие отрядов АК и вооруженных сил Красной Армии не привело к долгосрочному сотрудничеству, однако этому есть объяснение. Ставка Верховного главнокомандования позитивно отреагировала на запрос командующего фронтом о порядке взаимодействия с отрядами АК: оно допускалось при условии подчинения польской дивизии советскому командованию, при этом АК могла сохранять политические связи с любой властью, в том числе, с польским правительством в изгнании ${ }^{2}$. Польская же сторона разрешала военное взаимодействие дивизий АК с войсками Красной Армии только при условии восстановления дипломатических отношений Москвы с польским правительством в Лондоне. Для СССР этот вариант был невозможен и неприемлем ${ }^{3}$. Кроме того, власти СССР приняли во внимание донесения советских военных и партийных органов с Волыни, из других районов деятельности АК, что подстегнуло издание 20 апреля 1944 года директивы Ставки Верховного главнокомандования № 220088 о взаимоотношениях с подпольщиками, в которой приказывалось: «порвать всяческие сношения с подпольными отрядами генерала Соснковского». С этого момента разоружение отрядов АК и интернирование её офицерского корпуса стало основой действий Красной Армии по отношению к этой вооруженной организации, что привело к разрушению военной структуры подполья на польских территориях, освобожденных от гитлеровцев.

Детальное знание источников и фактов по заданному сюжету позволили исследователю создать цельную картину мероприятий, проводимых военным руководством АК с целью продолжить в 1944-1945 гг. борьбу против гитлеровцев и противостоять СССР. Автору также удалось проанализировать последовательность действий советских партийно-политических органов, направленных на то, чтобы удержать Польшу в сфере геополитического влияния СССР. Д. Рогут справедливо отмечает, что масштаб репрессий против солдат и офицеров АК был немалый и с лета 1944 года увеличивался и вглубь, затрагивая не только высшие командные чины, но и рядовых членов подполья, и вширь, охваты-

${ }^{2}$ См. Советский Союз и польское военно-политическое подполье, апрель 1943 г. - декабрь 1945 г.: в 3 т. Т. 1: Апрель 1943 г. - март 1944 г. Ч. 1. - Москва: МФД: Демократия, 2018. - C. 682-683.

${ }^{3}$ Подробнее см: Носкова А.Ф. Геополитические планы СССР и трагедия Армии Крайовой // STUDIA SLAVICA - POLONICA (К 90-летию И.И. Костюшко). Сборник статей / под редакцией К.В. Никифорова. - Москва: Институт славяноведения РАН, 2009. - С. 228-229. 
вая все новые территории. Однако представляется спорным тезис о том, что действия СССР шли вразрез с нормами международного права, поскольку, согласно Гаагской конвенции от 18 октября 1907 г., в военное время в тылу действующей армии не должно быть вооруженных людей, не подчиняющихся ее военному командованию. Исходя из этого положения, советские власти имели основания для ареста солдат и офицеров Армии Крайовой, носящих оружие и находящихся в тылу Красной Армии, в том числе и генерала Окулицкого, который отказался выйти из подполья и сложить оружие. Союзники же, несмотря на дипломатические усилия польского правительства в Лондоне, не могли противодействовать арестам польских офицеров АК, их инициативы носили исключительно рекомендательный характер и касались общих принципов уважения к правам человека.

Необходимо отметить, что на основе документов, приведенных в статье, подробно прослежена динамика изменения положения Армии Крайовой и ослабления позиций лондонского правительства на польских землях, происходивших на фоне возникновения ПКНО и его поддержки со стороны советского правительства. Однако, на наш взгляд, нельзя принимать за аксиому безусловность поддержки ПКНО советскими властями и тот факт, что с самого начала его существования взаимоотношение Кремля с польским правительством в изгнании было обречено на провал. СССР не сбрасывал со счетов вариант урегулирования отношений с правительством Станислава Миколайчика при условии изменения его состава ${ }^{4}$ и признания советско-польской границы по «линии Керзона».

Статья Д. Рогута актуальна тем, что еще раз заставляет задуматься не только над тем, был ли шанс на успех у АК в условиях занятия польских земель войсками Красной Армии, но и над тем, что проведение репрессивной политики на территории Польши высвечивало геополитические замыслы советского руководства, ведь репрессии против АК служили инструментом удержания Польши в сфере интересов СССР. Не стоит забывать и о геополитических замыслах польского правительства, и о его концепции использования силы при определении послевоенного будущего восточноевропейского региона, что обусловило инициативу АК начать Варшавское восстание и проведение акции «Буря». Если проблему деятельности советских органов госбезопасности рассматривать в контексте геополитических целей не только СССР, но и польского правительства в Лондоне, то становится понятным, что обе стороны пытались

${ }^{4}$ См: Польша в XX веке. Очерки политической истории / редакционная коллегия: Г.Ф. Матвеев, А.Ф. Носкова (ответственный редактор), Л.С. Лыкошина. - Москва: Индрик, 2012. - C. 425-426; Wasiewska W. Wspomnienia (1939-1944) // Archiwum Ruchu Robotniczego. - Warszawa: Książka i Wiedza, 1982. - T. VII. W 40 rocznicę powstania Polskiej Partii Robotniczej. - S. 40. 
обеспечить национально-государственные интересы посредством создания у своих границ пояса безопасных территорий.

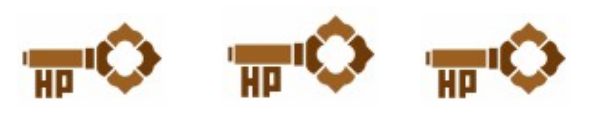

The problem of interaction between the Soviet authorities and the Home Army is the subject of extensive historiography. Special attention of researchers is paid to issues related to contacts between the units of the Red Army and of the detachments of the Home Army (Armia Krajowa, hereinafter AK) after January 1944. At that time, the Red Army crossed the pre-war border of Poland and in its rear there were partisan detachments of various ethnicities and different political views, including soldiers of the AK, by then the largest armed underground organization subordinated to the Polish government in London. This subject has not escaped the attention of Russian researchers.

The publication of a three-volume collection of documents under the title "The Soviet Union and the Polish Military and Political Underground, April 1943 December 1945,"1 among other things, confirms significant interest in this problem on the part of Russian historical science. In the context of the attitude of the Soviet authorities towards soldiers and officers of the AK, the compilers of the collection emphasized that from the beginning of 1944, the Soviet command was solving a difficult military and political task. The task was to prevent any actions of the armed groups which were not subordinated to them, in the rear. It resulted in disarmament and in the event of resistance, to suppression of the activities of partisan detachments and the internment of the AK officers. The way they addressed this task determined the attitude of the Soviet security agencies towards the AK.

The article by D. Rogut offered to the readers' attention is written on the basis of a profound knowledge of both contemporary Polish and Russian historiography and source materials. The author retraces the contacts of the Red Army and the AK detachments beginning from the spring of 1944, the moment of the short-term successful interaction of the $\mathrm{AK}$ with the troops of the $2^{\text {nd }}$ Belorussian Front in the fight against the Nazis. However, as D. Rogut rightly notes, as a result of these joint actions between the AK and the Red Army in the spring of 1944, permanent cooperation was not established. Moreover, part of the $27^{\text {th }}$ AK Infantry Division was disarmed by the Soviets. The author of the article does not indicate why the short

${ }^{1}$ A.N. Artizov, ed., Soviet Union and the Polish Military and Political Underground, April 1943 - December 1945 [in Russian], 3 vols. (Moscow: MFD: Demokratiya, 2018-2020). 
effective military interaction of the AK detachments and the armed forces of the Red Army did not lead to any long-term cooperation, but there is still an explanation for this fact. The headquarters of the Supreme High Command responded positively to the request of the front commander about the procedure for interaction with the AK detachments: it was allowed provided that the Polish division would be subordinated to the Soviet command, while the Home Army could maintain political ties with any government, including the Polish government in exile. ${ }^{2}$ The Polish side, on the other hand, permitted military interaction between the AK divisions and the Red Army troops only on condition that the diplomatic relations between Moscow and the Polish government in London were restored. For the USSR, this option was impossible and completely unacceptable. ${ }^{3}$ In addition, the USSR authorities took into consideration the reports of the Soviet military and party bodies from Volhynia and from other areas of the AK activities, which urged the issue of the directive of the Supreme Command Headquarters no. 220088 dated April 20, 1944 on relations with the underground. The directive ordered "to break all relations with the underground units of General Sosnkowski." From that moment on, the disarmament of the AK detachments and the internment of its officer corps became the basis for the actions of the Red Army in relation to this armed organization, which led to the destruction of the military structure of the political underground in the Polish territories liberated from the Nazis.

Deep knowledge of sources and facts on the historical subject allowed the researcher to create a complete picture of the activities carried out by the military leadership of the AK in 1944-45 with the main purpose of continuing the fight against the Nazis and the simultaneous confrontation with the USSR. The author also succeeded in analysing the sequence of actions of the Soviet party and political bodies, aimed at keeping Poland in the sphere of geopolitical influence of the USSR. D. Rogut rightly notes that the scale of repression against soldiers and officers of the Home Army was significant and had even increased since the summer of 1944 both in depth, affecting not only the highest command but also ordinary members of the underground, and in breadth, covering more and more territories. However, the thesis that the actions of the USSR contravened the norms of international law seems quite controversial since according to The Hague Convention of October 18, 1907, in wartime, there should be no armed people in the rear of the active army who do not obey its military command. Following this stance, the Soviet authorities had every

${ }^{2}$ See Soviet Union and the Polish military and political underground, April 1943 - December 1945, vol. 1, April 1943 - March 1944, pt. 1 (Moscow: MFD: Demokratiya, 2018), 682-83.

${ }^{3}$ For more, see A.F. Noskova, "Geopolitical Plans of the USSR and the Tragedy of the Home Army" [in Russian], in STUDIA SLAVICA - POLONICA (To the 90 ${ }^{\text {th }}$ anniversary of I.I. Kostyushko). A collection of articles, ed. K.V. Nikiforov (Moscow: Institut slavyanovedeniya RAN, 2009), 228-29. 
right to arrest any soldiers and officers of the Home Army carrying weapons and located in the rear of the Red Army, including General Okulicki who had refused to emerge from the underground and lay down his arms. Despite the diplomatic efforts of the Polish government in London, the allies could not oppose the arrests of AK Polish officers; their initiatives were purely advisory in nature and related to general principles of respect for human rights.

It should also be noted that, on the basis of the documents presented in the article, the dynamics of the change in the position of the Home Army and the weakening of the position of the London government on Polish lands, which took place in the context of the emergence of the Polish Committee of National Liberation (PKWN) and its support by the Soviet government were retraced in detail. However, in our opinion, the unconditional support of the PKWN by the Soviet authorities and the fact that from the very beginning of its existence the relationship between the Kremlin and the Polish government in exile was doomed to failure should not be taken as self-evident. The USSR still did not completely rule out settlement of relations with the government of Stanisław Mikołajczyk subject to changes in its composition and the recognition of the Soviet-Polish border along the Curzon Line. ${ }^{4}$

The article of $\mathrm{D}$. Rogut is topical because it makes us think once again not only about the question if the AK had a chance of success in the conditions of the occupation of Polish lands by the Red Army, but also about the fact that the pursuit of a repressive policy in Poland highlighted the geopolitical intentions of the Soviet leadership because the repressions against the AK served as an instrument to keep Poland in the sphere of interests of the USSR. The geopolitical plans of the Polish government should also be kept in mind, as well as its intention of using force in determining the post-war future of the Eastern European region, which led to the initiative of the AK to start the Warsaw Uprising and Operation Tempest. If the problem of the activities of the Soviet state security bodies is considered in the context of the geopolitical goals of not only the USSR but also of the Polish government in London, it becomes clear that both sides tried to ensure national and state interests by creating a zone of safe territories near their borders.

\section{Список литературы}

Польша в XX веке. Очерки политической истории / Редакционная коллегия: Г.Ф. Матвеев, А.Ф. Носкова (ответственный редактор), Л.С. Лыкошина. - Москва: Индрик, 2012. $-952 \mathrm{c}$.

${ }^{4}$ See G.F. Matveev, A.F. Noskova, and L.S. Lykoshina, eds., Poland in the $20^{\text {th }}$ Century. Essays on Political History [in Russian] (Moscow: Indrik, 2012); W. Wasiewska, "Wpomnienia (1939-1944)," in Archiwum Ruchu Robotniczego, vol. 7, W 40 rocznice powstania Polskiej Partii Robotniczej (Warsaw: Książka i Wiedza, 1982), 40. 
Носкова А.Ф. Геополитические планы СССР и трагедия Армии Крайовой // STUDIA SLAVICA - POLONICA (К 90-летию И.И. Костюшко). Сборник статей / под редакцией К.В. Никифорова. - Москва: Институт славяноведения РАН, 2009. - С. 217-244.

Советский Союз и польское военно-политическое подполье, апрель 1943 - декабрь 1945: в 3 т. Т. 1. Апрель 1943 г. - март 1944 г. Ч. 1 / ответственный редактор А.Н. Артизов. - Москва: МФД: Демократия, 2018. - 783 с.

Wasiewska W. Wspomnienia // Archiwum ruchu robotniczego. - Warszawa: Książka i Wiedza, 1982. - T. VII. W 40 rocznicę powstania Polskiej Partii Robotniczej. - S. 339-432.

\section{References}

Artizov, A.N., ed. Sovetskii Soyuz i pol'skoe voenno-politicheskoe podpol'e, aprel' 1943 dekabr' 1945 [Soviet Union and the Polish military and political underground, April 1943 December 1945]. 3 vols. Vol. 1, Aprel' 1943 g. - mart 1944 g. [April 1943 - March 1944]. Pt. 1. Moscow: MFD: Demokratiya, 2018. (In Russian)

Matveev, G.F., A.F. Noskova, and L.S. Lykoshina, eds. Pol'sha v XX veke. Ocherki politicheskoi istorii [Poland in the $20^{\text {th }}$ century. Essays on political history]. Moscow: Indrik, 2012. (In Russian)

Noskova, A.F. "Geopoliticheskie plany SSSR i tragediya Armii Kraiovoi” [Geopolitical plans of the USSR and the tragedy of the Home Army]. In STUDIA SLAVICA - POLONICA (K 90-letiyu I.I. Kostyushko). Sbornik statei [STUDIA SLAVICA - POLONICA (To the $90^{\text {th }}$ anniversary of I.I. Kostyushko). A collection of articles], edited by K.V. Nikiforov, 217-44. Moscow: Institut slavyanovedeniya RAN, 2009. (In Russian)

Wasiewska, W. "Wpomnienia (1939-1944)." In Archiwum Ruchu Robotniczego, vol. 7, W 40 rocznice powstania Polskiej Partii Robotniczej, 339-432. Warsaw: Książka i Wiedza, 1982.

Елена Борисовна Лопатина

Кандидат исторических наук,

Старший научный сотрудник

Института славяноведения РАН, Москва, Россия https://orcid.org/0000-0002-7718-400X, ellolebo@gmail.com
Elena B. Lopatina

Candidate of Historical Sciences, Senior Researcher Institute for Slavic Studies of the RAS, Moscow, Russia https://orcid.org/0000-0002-7718-400X, ellolebo@gmail.com 